\title{
SPATIAL AND TEMPORAL DISTRIBUTION OF "CURVINA" LARVAE (Plagioscion squamosissimus HECKEL, 1840) AND ITS RELATIONSHIP TO SOME ENVIRONMENTAL VARIABLES IN THE UPPER PARANÁ RIVER FLOODPLAIN, BRAZIL
}

\author{
BAUMGARTNER, M. S. T., ${ }^{1,2}$ NAKATANI, K., ${ }^{1,3}$ \\ BAUMGARTNER, G. ${ }^{4}$ and MAKRAKIS, M. C. ${ }^{4}$ \\ ${ }^{1}$ Universidade Estadual de Maringá, Departamento de Biologia, Pós-graduação em Ecologia de Ambientes \\ Aquáticos Continentais, Av. Colombo, 5790, Bloco G90, CEP 87020-900, Maringá, Paraná, Brazil \\ ${ }^{2}$ Universidade Paranaense, UNIPAR, Curso de Ciências Biológicas, Av. Parigot de Souza, 3636, \\ Jd. Prada, CEP 85903-170, Toledo, Paraná, Brazil \\ ${ }^{3}$ Núcleo de Pesquisas em Limnologia, Ictiologia e Aqüicultura, Nupélia, Universidade Estadual de Maringá, \\ Av. Colombo, 5790, Bloco H90, CEP 87020-900, Maringá, Paraná, Brazil \\ ${ }^{4}$ Universidade Estadual do Oeste do Paraná, Curso de Engenharia de Pesca, Rua da Faculdade, 645, \\ CEP 85903-000, Toledo, Paraná, Brazil \\ Correspondence to: Maria do Socorro Tenório Baumgartner, Universidade Paranaense, Av. Parigot de Souza, 3636, \\ Jardim Prada, CEP 85903-170, Toledo, Paraná, Brazil, e-mail: sgmbaum@uol.com.br \\ Received July 16, 2002 - Accepted November 27, 2002 - Distributed August 31, 2003
}

(With 6 figures)

\begin{abstract}
With the objective of studying the spatial and temporal distribution of "curvina" Plagioscion squamosissimus larvae and verifying respective spawning sites, monthly sampling was carried out from March 1993 to February 1994 on the Upper Paraná River floodplain. Using a conical-cylindrical plankton net $(0.5 \mathrm{~mm}$ mesh), samples were taken from the surface of the water bodies, and in the marginal vegetation a strainer and a dragnet ("picaré") were used. Water samples were collected for environmental variable analysis (temperature, dissolved oxygen, water $\mathrm{pH}$, and electrical conductivity). Water level data were obtained from hydrometric stations. High average density of larvae was found from December 1993 to February 1994 due to high temperature and water level. The Baía sub-area was shown to be the most important in the larvae catch, probably due to its semi-lotic characteristics. Larvae size distribution was shown to be more frequent in the $4.0 \mathrm{~mm}$ standard length class, indicating that the sampling stations were next to the spawning sites.
\end{abstract}

Key words: "Curvina" larvae, Plagioscion squamosissimus, distribution, floodplain, Upper Paraná River.

\section{RESUMO}

Distribuição espacial e temporal de larvas da curvina

(Plagioscion squamosissimus HECKEL, 1840) e sua relação com algumas variáveis ambientais na planície de inundação do alto rio Paraná, Brasil

Coletas mensais foram realizadas no período de março de 1993 a fevereiro de 1994 na planície de inundação do alto rio Paraná, com o objetivo de estudar a distribuição espacial e temporal de larvas da curvina Plagioscion squamosissimus e verificar a localização de áreas de desova da espécie. Amostragens foram efetuadas na superfície dos corpos de água com rede de plâncton cônico-cilíndrica, de malha $0,5 \mathrm{~mm}$, e na vegetação marginal com "peneirão" e rede de arrasto do tipo "picaré". Amostras de água foram coletadas para análise de fatores ambientais (temperatura, oxigênio dissolvido, $\mathrm{pH}$ e condutividade elétrica) e dados de nível fluviométrico foram obtidos de estações hidrométricas. Maiores 
densidades médias de larvas foram verificadas de dezembro/93 a fevereiro/94, relacionadas a elevada temperatura e nível da água. A subárea Baía foi a mais importante na captura de larvas, provavelmente por suas características semilóticas. A distribuição por tamanho das larvas mostrou maior freqüência na classe de 4,0 mm de comprimento-padrão, indicando que as estações de coleta localizavam-se próximas dos locais de desova.

Palavras-chave: larvas de curvina, Plagioscion squamosissimus, distribuição, planície de inundação, alto rio Paraná.

\section{INTRODUCTION}

Fluvial floodplains are characterized by habitat heterogeneity and are recognized as the natural nurseries of many fish species (Paiva, 1982; Junk et al., 1989). Fish communities that inhabit these ecosystems are adapted to their dynamics and need these places to complete their life cycle. Fish that inhabit floodplain rivers show reproductive habits that make them apt to reproduce in this ecosystem with its fast surging water level and capable of withstanding extreme physical and chemical conditions (Welcomme, 1979).

The majority of floodplain fish species spawn when the water level starts to rise, guaranteeing that the young are produced during the period when conditions are most favorable to their survival, i.e., when food is found in abundance, allowing fast growth and protection against predators (LoweMcConnell, 1975; Baumgartner et al., 1997).

Plagioscion squamosissimus (Heckel, 1840) ("curvina") has a prominent place in professional fishing in six São Paulo Electric Company (CESP) reservoirs (Torloni et al., 1993). A species originally from the Amazon Basin, it was introduced in the Pardo River Basin in 1967 (Machado, 1974; Nomura, 1984) and also has an important role in Itaipu Reservoir fishery (Agostinho et al., 1994; Okada et al., 1996). For the stretch between the mouth of the Paranapanema River and Itaipu Reservoir, some studies on this species are available, among which are found references to fishing production (Agostinho et al., 1994; Okada et al., 1996), larvae distribution (Baumgartner \& Nakatani, 1997; Baumgartner et al., in prep.), and fish life associated with large leaf plants (Delariva et al., 1994). However, on the alluvial floodplain and in the Upper Paraná River tributaries, little is known about the destiny of eggs and larvae from different fish species.

The objective of our study was to analyze the spatial and temporal distribution of Plagioscion squamosissimus larvae on the Upper Paraná River floodplain (relating them to some environmental variables: temperature, dissolved oxygen, water $\mathrm{pH}$, electrical conductivity, and water level), and verify the proximity of the sampling stations to possible spawning sites by using analyses of the size of the captured larvae.

Thus, we obtain better species knowledge of this ecosystem, which above all concerns the habitat occupation process by introduced species.

\section{Characterization of sub-area sampling}

The 36 sampling stations selected for this study were located on the Upper Paraná River floodplain

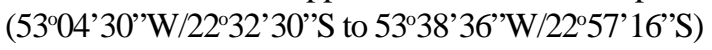
in a stretch that includes right tributaries of the Paraná River - the Baía River and the Ivinheima River in its lower segment (Fig. 1).

The stations were grouped in 4 sub-areas whose characteristics were obtained through field observation.

Paranapanema sub-area: contains 10 sampling stations (nos. 1 to 8, 35 and 36), located in the Paraná River. Station 2 was located at the mouth of the Paranapanema River. Except for station 8, which has lentic surroundings that can acquire flow during high water level periods, all the other stations have lotic surroundings since they are located on the riverbank.

Paraná sub-area: also located in the Paraná River, in a stretch below the above sub-area, it includes 8 sampling stations (nos. 9 to 16). It has lotic surroundings where large leaf aquatic plants are scarce, except at station 10 (Cortado), which constitutes a section of the Paraná River where the abundant presence of this type of vegetation is a constant, even though it has high water flow.

Ivinheima sub-area: groups 7 sampling stations located in the Ivinheima River (nos. 17 to 22 and 24), and 2 in Araçatuba Channel (nos. 23 and 25). Large leaf aquatic plant banks occur at stations 17 (Pintado's Lagoon), 21 (Pato's Lagoon), 22 (Finado Raimundo's Lagoon), and 23 (Sumida Lagoon) (all lentic environments). All the other stations have lotic characteristics. 


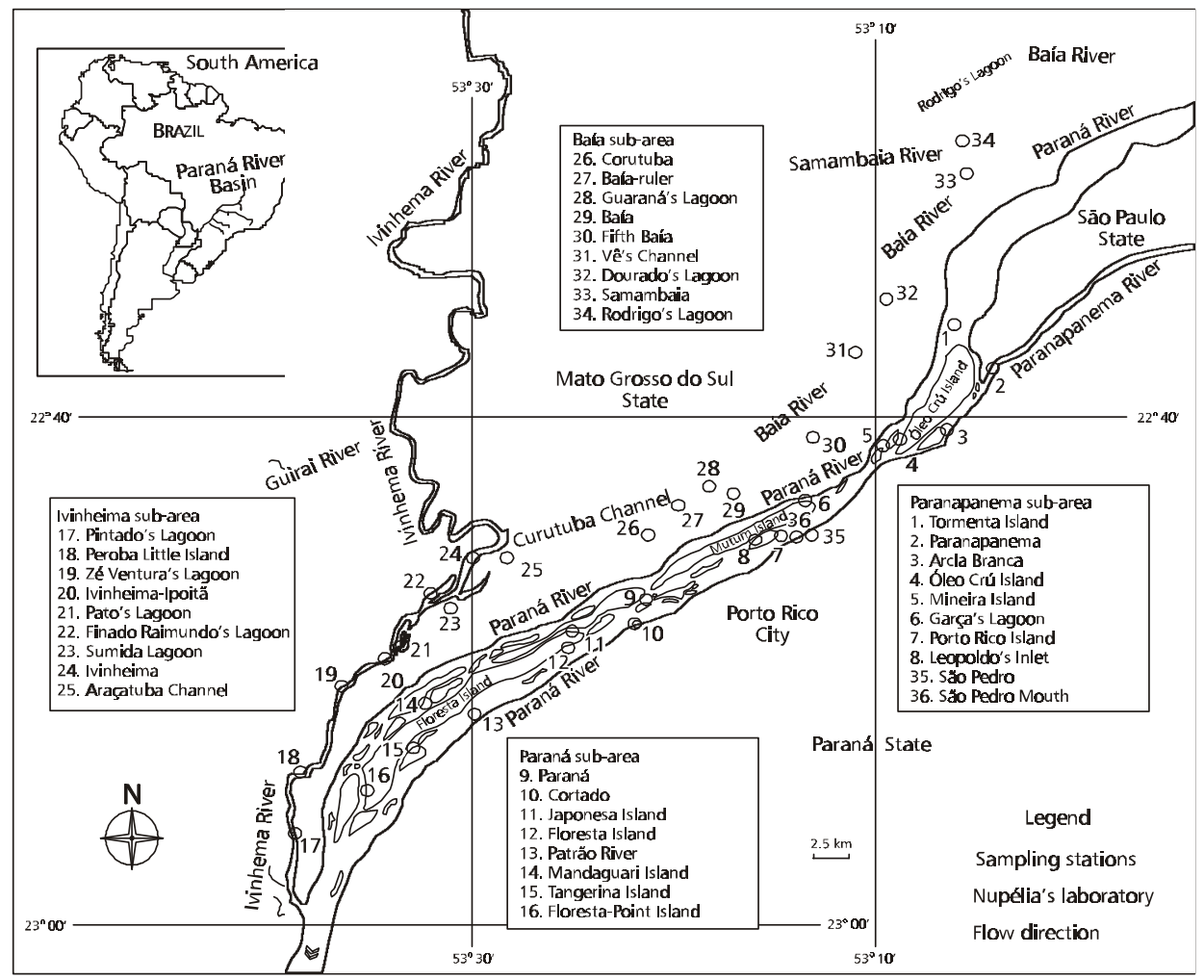

Fig. 1 - Locations of the sub-areas and sampling stations.

Baía sub-area: encompasses stations 26 to 34 located in the Baía River, mostly characterized as semi-lotic environments, except for stations 28 (Guaraná's Lagoon) and 34 (Rodrigo's Lagoon), which are lentic.

\section{MATERIAL AND METHODS}

Plankton samples were collected monthly from all the previously mentioned 36 stations from March 1993 to February 1994. Sampling from the surface began right after sunset using a $0.5 \mathrm{~mm}$ plankton net with a flow meter attached. Sweeps lasted for 10 minutes and sampling was preserved with $4 \%$ neutralized formalin. The samples were taken only at night based on previous studies (Nakatani et al., 1993; Baumgartner \& Nakatani, in prep.) showing high catch in this period.

Samples were taken using a strainer and a dragnet "picaré" at the Paraná (9), Cortado (10), Ivinheima-Ipoitã (20), Pato's Lagoon (21), Baía (29), and Guaraná's Lagoon (28) stations. The strainer was launched over the aquatic plant banks and the dragnet "picaré" was dragged on small beaches formed at the Cortado, Pintado's Lagoon, and Baía stations.

At the Samambaia (33), Rodrigo's Lagoon (34), São Pedro (35), and São Pedro Mouth (36) stations, monthly samples were collected at 6 p.m., 10 p.m., 2 a.m., and 6 a.m., with the objective of verifying the larvae occurrence variation at night. The samples taken at 10 p.m. at these stations were considered in the analysis of the spatial and temporal distribution of the larvae because it was the time closest to that of the sampling at the other stations.

Water samples were taken using a Van Dorn bottle to analyze the environmental variables: temperature, dissolved oxygen, water $\mathrm{pH}$, and electrical conductivity. Water temperature was determined using a mercury bulb thermometer. Water $\mathrm{pH}$ values and electrical conductivity were determined using a portable $\mathrm{pH}$ meter and a conductivimeter. Samples to determine dissolved oxygen concentrations were taken and analyzed according to the Winkler method, modified by Golterman et al. (1978). 
Larvae were separated from the remaining plankton on a Bogorov acrylic plate under a stereomicroscope (10x). Larvae identification was done based on a development series of Plagioscion squamosissimus larvae obtained from systematic sampling in the study area since 1986 and from Nakatani et al. (1997).

Larvae abundance was standardized to a filtered water volume of $10 \mathrm{~m}^{3}$, according to a modified Tanaka method (1973). The average density of the larvae was obtained using the following equation: $\mathrm{DM}=\mathrm{C} / \mathrm{B}$, where $\mathrm{DM}=$ average density of the larvae, $\mathrm{C}=$ total density of the collected larvae, and $\mathrm{B}=$ total samples taken in each month or total months in each station.

Daily water level readings of the Paraná River taken at Porto São José Hydrometrical Station, São Pedro do Paraná (Paraná State), and daily readings from the Ivinheima River taken at Porto Sumeca Hydrometrical Station (Amandina district), Ivinheima (Mato Grosso do Sul State), were obtained from the National Department of Water and Electrical Energy (DNAEE). The hydrometrical level values considered in this study were those from the day that the samples were collected.

The values of the abiotic variables and the average density of the larvae were previously standardized $[\log (x+1)]$ due to different measurement units. With the purpose of verifying dependence between environmental variables, a Principal Component Analysis was applied considering the separated sub-areas (Mainly, 1995) using the package PCOrd 2.0 (McCune \& Mefford, 1995). The principal components retained for interpretation were those that showed eigenvalues higher than 1.0 (one), according to the criteria of Keiser-Gutman (Jackson, 1993). The variables that presented a structure coefficient higher than 0.5 were considered biologically important (Hair et al., 1994).

To verify biotic variables and larvae occurrence interrelationship, the Pearson Correlation test was applied to the average density logarithm and the Principal Component scores kept for interpretation, using the package STATISTICA ${ }^{\text {TM }} 5.0$ (Statsoft, 1999).

To analyze the size of the captured larvae, standard length measurements were taken using a stereomicroscope equipped with a micrometrical eyepiece. Distribution was done by class.

\section{RESULTS}

During the study period, 470 Plagioscion squamosissimus larvae were caught using a plankton net. No larvae were collected using the strainer and dragnet "picaré" on aquatic plants banks or small beaches.

\section{Spatial and temporal occurrence of larvae}

The results shown here refer to a total of 257 captured larvae. The larvae were caught over almost the entire study period, except from June to September 1993, and the largest occurrence was verified from December 93 to February 94 (Fig. 2).

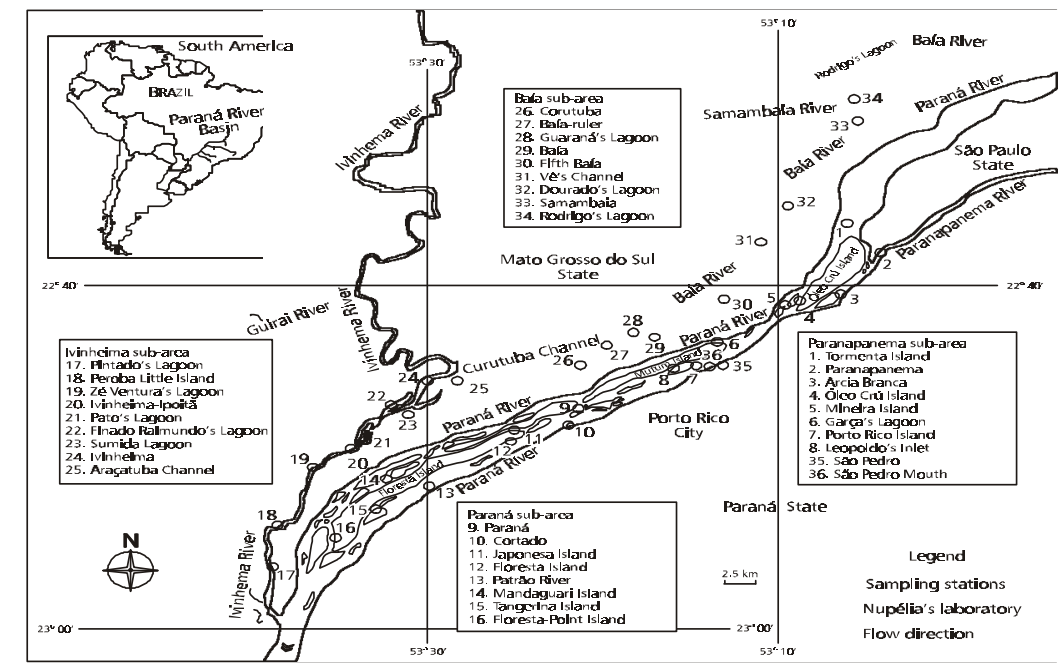

Fig. 2 - Monthly average densities (square) and standard error (bar) of Plagioscion squamosissimus larvae. 
"Curvina" larvae were caught in 23 of the 36 sampling stations. Higher average densities were verified in the Baía sub-area (Fig. 3), especially at the Samambaia (33) and Rodrigo's Lagoon (34) stations.

Table 1 shows that the sub-areas displayed close average values of temperature and fluviometric level. The lower average values of dissolved oxygen, water $\mathrm{pH}$, and electrical conductivity were observed in the Baía sub-area.

Table 2 shows the results of the Principal Component analyses between the environmental variables and the results of the Pearson's Correlation between this analysis score and the larvae average density logarithms in each sub-area. From the possible principal components, only PC 1 and 2 from the four sub-areas were used for interpretation since their eigenvalues were higher than 1.0.

The PC 1 and 2 of the Paranapanema sub-area accounted for $86.80 \%$ of data variability. The PC 1 showed an eigenvalue of 2.802. Variables that contributed positively to form this axis were water level and temperature; negatively, they were dissolved oxygen and water $\mathrm{pH}$. The PC 2 showed an eigenvalue of 1.538 and was influenced positively by water $\mathrm{pH}$ and temperature, and negatively by electrical conductivity.

The PC 1 and 2 of the Paraná sub-area accounted for $85.47 \%$ of data variability. The PC 1 (eigenvalue $=2.536$ ) showed a positive relationship with dissolved oxygen and electrical conductivity, and a negative relationship with temperature and water level. On the other hand, PC 2 (eigenvalue = 1.737) was positively influenced by water $\mathrm{pH}$ and negatively by electrical conductivity and water level.

The PC 1 and 2 of the Ivinheima sub-area contributed to $88.05 \%$ of data variability, where PC 1 (eigenvalue $=3.246$ ) showed a positive relationship with water level, electrical conductivity, and temperature, and a negative relationship with dissolved oxygen, whereas PC 2 (eigenvalue = 1.157) showed a positive relationship with water $\mathrm{pH}$ and temperature.

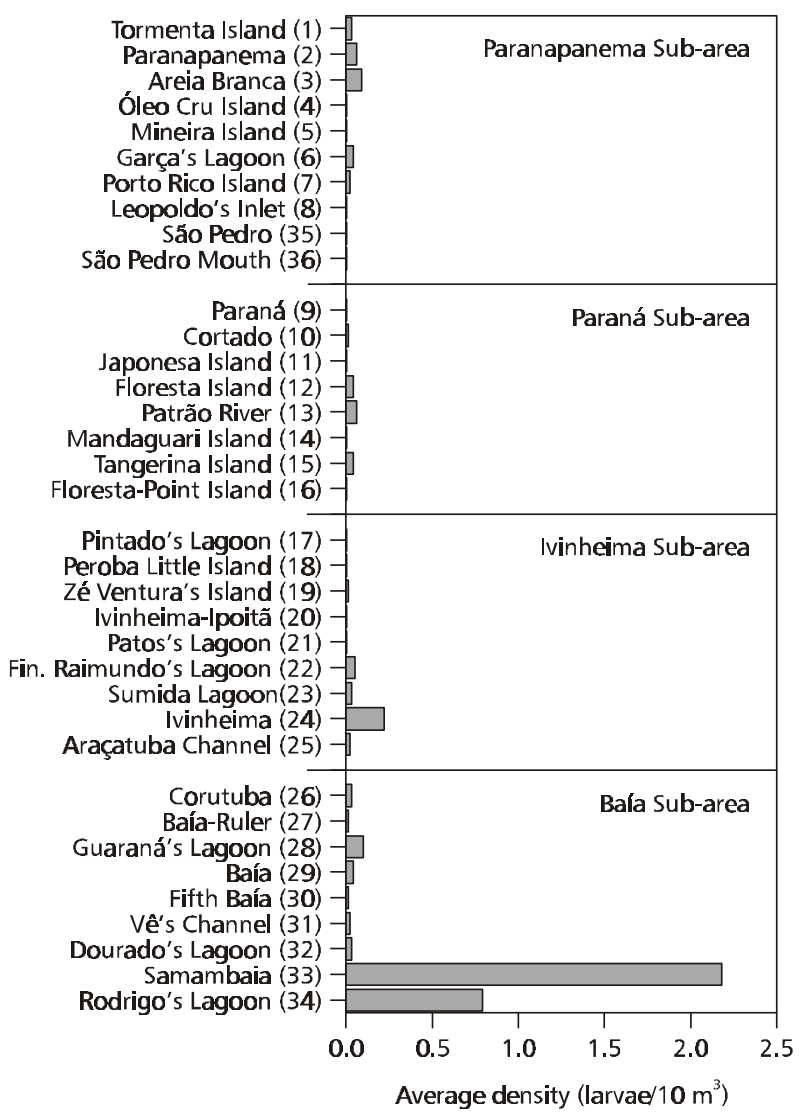

Fig. 3 - Larvae average densities of Plagioscion squamosissimus in the sub-areas and sampling stations. 
TABLE 1

Average values of the environmental variables and standard error (temperature, dissolved oxygen, water $\mathrm{pH}$, electrical conductivity, and water level on sampling day) obtained during the study period.

\begin{tabular}{|l|c|c|c|c|c|c|c|c|}
\hline \multirow{2}{*}{ Variables } & Paranapanema & \multicolumn{2}{c|}{ Paraná } & \multicolumn{2}{c|}{ Ivinheima } & \multicolumn{2}{c|}{ Baía } \\
\cline { 2 - 10 } & Avg & sd & Avg & sd & Avg & sd & Avg & sd \\
\hline Water temperature $\left({ }^{\circ} \mathrm{C}\right)$ & 25.76 & 0.29 & 25.54 & 0.38 & 25.53 & 0.39 & 25.42 & 0.37 \\
\hline Dissolved oxigen $\left(\mathrm{mgL}^{-1}\right)$ & 8.09 & 0.08 & 8.28 & 0.09 & 7.06 & 0.20 & 5.83 & 0.24 \\
\hline $\mathrm{pH}$ & 7.29 & 0.03 & 7.45 & 0.03 & 7.04 & 0.06 & 6.52 & 0.06 \\
\hline Electrical condutivity $\left(\mu \mathrm{Scm}^{-1}\right)$ & 51.56 & 0.53 & 54.66 & 0.54 & 38.55 & 0.68 & 26.14 & 0.82 \\
\hline Fluviometric level $(\mathrm{m})$ & 3.64 & 0.08 & 3.64 & 0.09 & 3.68 & 0.09 & 3.60 & 0.08 \\
\hline
\end{tabular}

TABLE 2

Results of the Principal Component Analysis applied to environmental variables (temperature, dissolved oxygen, water $\mathrm{pH}$, electrical conductivity, and water level on sampling day) and Pearson's Correlation between the Principal Component scores and the larvae average density logarithms of Plagioscion squamosissimus in the four sub-areas studied.

\begin{tabular}{|l|c|c|c|c|c|c|c|c|}
\hline \multirow{2}{*}{ Variables/Components } & \multicolumn{2}{|c|}{ Paranapanema } & \multicolumn{2}{c|}{ Paraná } & \multicolumn{2}{c|}{ Ivinheima } & \multicolumn{2}{c|}{ Baía } \\
\cline { 2 - 10 } & PC1 & PC2 & PC1 & PC2 & PC1 & PC2 & PC1 & PC2 \\
\hline Water temperature $\left({ }^{\circ} \mathrm{C}\right)$ & 0.736 & 0.506 & -0.902 & 0.001 & 0.710 & $\mathbf{0 . 6 1 9}$ & $\mathbf{0 . 7 7 7}$ & 0.309 \\
\hline Dissolved oxigen $\left(\mathrm{mgL}^{-1}\right)$ & -0.966 & -0.096 & 0.889 & 0.131 & -0.910 & 0.157 & $-\mathbf{0 . 9 1 8}$ & 0.273 \\
\hline $\mathrm{pH}$ & -0.732 & 0.574 & -0.085 & 0.926 & -0.452 & $\mathbf{0 . 8 6 0}$ & -0.498 & 0.856 \\
\hline $\begin{array}{l}\text { Electrical condutivity } \\
\left(\mu \mathrm{Scm}^{-1}\right)\end{array}$ & 0.106 & -0.969 & 0.607 & -0.744 & 0.899 & 0.003 & $\mathbf{0 . 9 1 4}$ & 0.237 \\
\hline Fluviometric level $(\mathrm{m})$ & 0.883 & 0.064 & -0.747 & -0.555 & 0.939 & 0.097 & $\mathbf{0 . 8 3 9}$ & 0.262 \\
\hline Autovalues & 2.802 & 1.538 & 2.536 & 1.737 & 3.246 & 1.157 & 3.234 & 1.028 \\
\hline$\%$ of explanation & 56.04 & 30.76 & 50.73 & 34.74 & 64.91 & 23.14 & 64.67 & 20.56 \\
\hline Pearson correlation & 0.343 & 0.223 & -0.413 & -0.437 & -0.036 & 0.728 & 0.637 & 0.105 \\
\hline Probability & $\mathbf{n s}$ & $\mathbf{n s}$ & $\mathbf{n s}$ & $\mathbf{n s}$ & $\mathbf{n s}$ & 0.007 & 0.026 & $\mathbf{n s}$ \\
\hline
\end{tabular}

ns - not significant at the significancy level adopted $(\mathrm{p}<0.05)$.

The PC 1 and 2 of the Baía sub-area accounted for $85.23 \%$ of data variability. The PC 1 (eigenvalue = 3.234) showed a positive relationship with electrical conductivity, water level, and temperature and a negative relationship with dissolved oxygen, whereas PC 2 (eigenvalue $=1.028$ ) showed a positive relationship with water $\mathrm{pH}$.

Pearson's Correlation between the Principal Component Analysis scores applied to the environmental variables and the larvae average density logarithm showed a significant correlation only with PC 2 of the Ivinheima sub-area and PC 1 of the Baía sub-area (Table 2).

In the Ivinheima sub-area (Fig. 4a), average densities of larvae were shown to be higher when water $\mathrm{pH}$ and temperature values were higher. In the Baía sub-area (Fig. 4b), average densities of larvae were higher when temperature, electrical conductivity, and water level were higher and dissolved oxygen presented lower concentrations. These conditions were verified from December 93 to February 94. 


\section{Nighttime larvae occurrence}

Nighttime larvae occurrence results correspond to a total of 400 larvae caught at Samambaia (33) and Rodrigo's Lagoon (34) stations.

At São Pedro and São Pedro Mouth stations only one larva was captured (São Pedro Mouth) during the entire study period. At Samambaia station (Fig. 5), where the largest catch took place, larvae occurrence was verified from October 93 to April 94 , with the highest average density between December 93 and January 94. The highest larvae average density for this station was verified between 10 p.m. and 2 a.m.

At Rodrigo's Lagoon station, "curvina" larvae occurrence was also from October 93 to April 94, with the highest average density in December 93 and February 94. Capture peaked at 2 a.m.
Larvae distribution by standard length class (SL)

Larvae distribution by standard length class in different sub-areas (A) and at Samambaia and Rodrigo's Lagoon stations (B) (Fig. 6) showed that the smallest larvae were captured in the Baía and Paranapanema sub-areas ( $2 \mathrm{~mm}$ ). In the Paranapanema sub-area, larvae frequency was higher in the $6.00 \mathrm{~mm}$ class, while in the Paraná sub-area the highest frequency was confirmed in the $4.0 \mathrm{~mm}$ class. The Ivinheima sub-area stood out because of the occurrence of larger larvae (above $6.0 \mathrm{~mm}$ ). In the Baía sub-area there was a high frequency of $4.0 \mathrm{~mm}$ larvae, followed by that of the $6.0 \mathrm{~mm}$ class. At the Samambaia and Rodrigo's Lagoon stations the highest larvae frequency was obtained in the $4.0 \mathrm{~mm}$ class. It is worth mentioning that at Rodrigo's Lagoon the second highest frequency was in the $2.0 \mathrm{~mm}$ class.

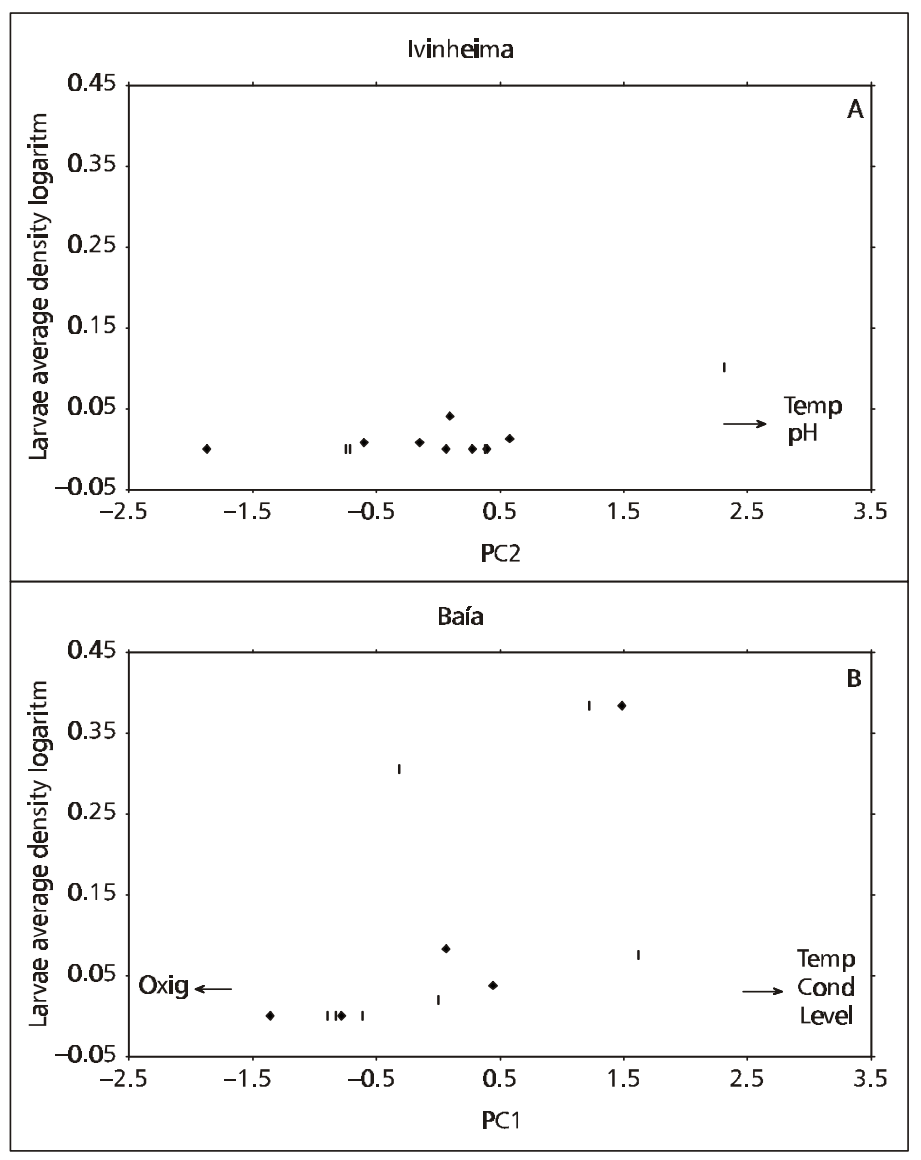

Fig. 4 - Pearson's Correlation between the scores of the Principal Component Analysis applied to the environmental variables (temperature, dissolved oxygen, water $\mathrm{pH}$, electrical conductivity, and water level on sampling day) and the larvae average density logarithms $[\log$ de $(x+1)]$ of Plagioscion squamosissimus in the Baía and Ivinheima sub-areas. 

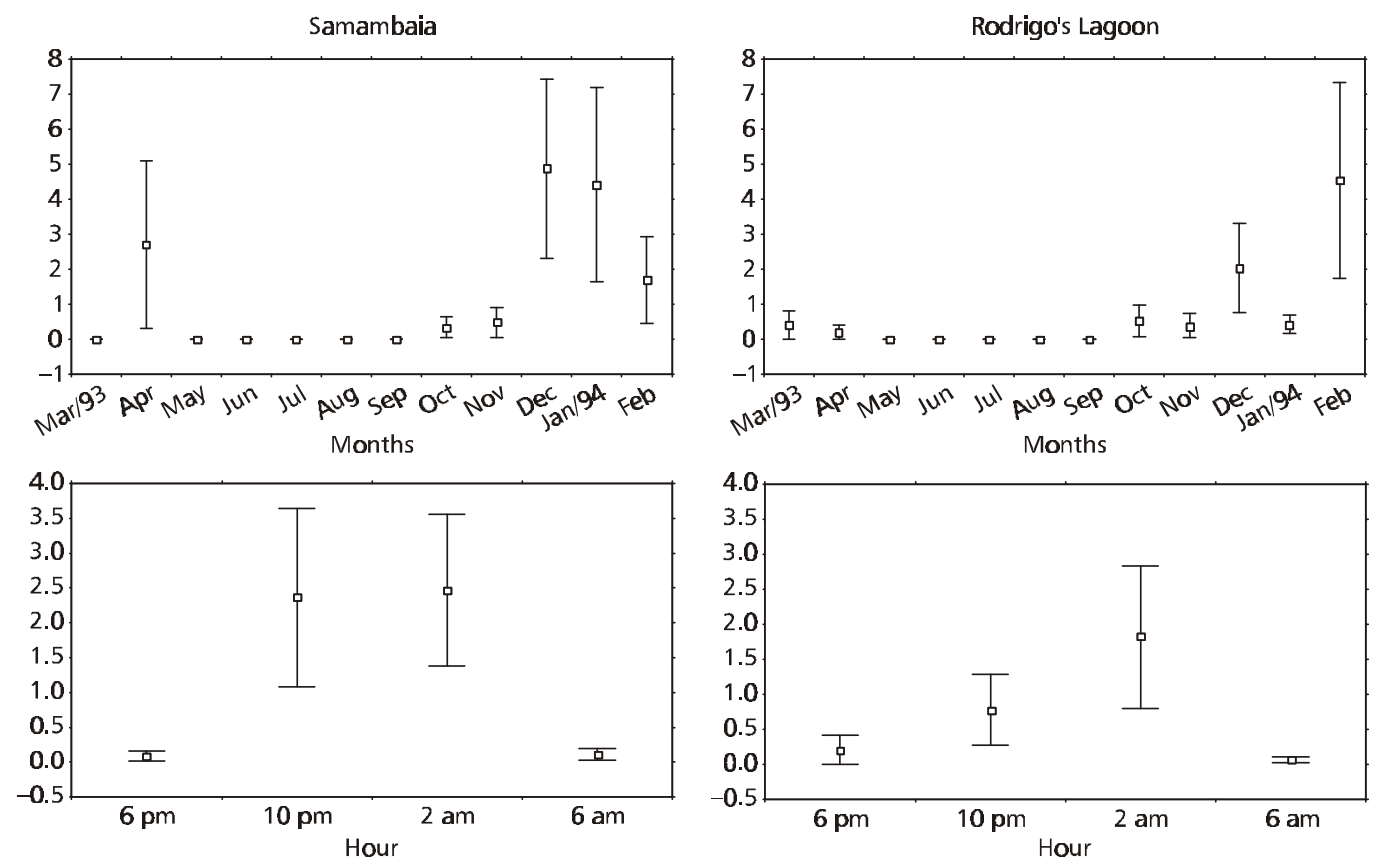

Fig. 5 - Monthly average densities and sampling time-table (square) and standard error (bar) for Plagioscion squamosissimus larvae caught at the Samambaia and Rodrigo's Lagoon stations at night.

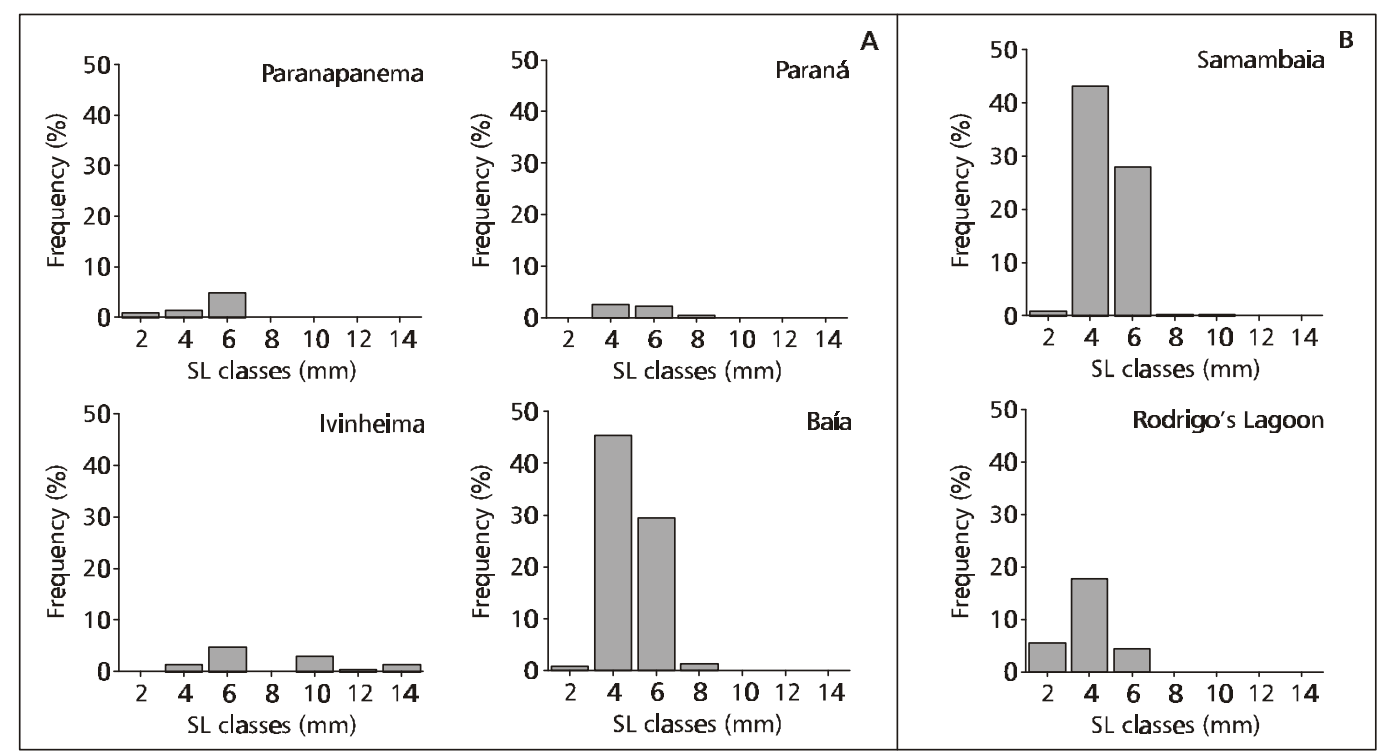

Fig. 6 - Frequencies by standard length classes (SL) for Plagioscion squamosissimus larvae caught in the analyzed sub-areas and at the Samambaia and Rodrigo's Lagoon stations. 


\section{DISCUSSION}

In this study, capture of Plagioscion squamosissimus larvae occurred only in the plankton sampling, showing the planktonic habit of these larvae. This observation lends weight to the study of fish fauna associated with aquatic plant banks in a floodplain environment carried out by Delariva et al. (1994) which showed few immature individuals of this species in these banks during high water level periods. Thus, we establish that the species occupy pelagic environments at different stages of its life cycle.

The seasonal pattern of Plagioscion squamosissimus larvae distribution, with high density during high water-level season (shown by Pearson's Correlation), confirms data showing that most fish reproduction in floodplain rivers is highly seasonal and coincides with initial flood phases (Welcomme, 1979). Thus, many aspects of the flood regime can impact spawning success or offspring survival, thus influencing fish stock recruitment (Welcomme, 1979). Esteves (1988) affirms that high water levels cause alterations in aquatic communities (e.g., by influencing processes occurring within the fish community like feeding, migration stimulation, spawning, and egg and larvae survival) by physically and chemically changing water conditions, especially in water-level elevation. A previous study (October 87 to September 88) carried out on this floodplain showed that flood absence resulted in low catches of fish larvae (Baumgartner \& Nakatani, in prep.).

In relation to seasonality in the reproductive period, studies on the larvae of this species in Itaipu Reservoir showed results similar to ours, with largest occurrence from December to April (Nakatani et al., 1993). According to Vazzoler (1996), based on reproductive behavior of teleost species in the Upper Paraná River, non-migrating species like Plagioscion squamosissimus have a well-defined spawning peak between November and February, which could extend from October to March (Vazzoler et al., 1997). Nevertheless, a differentiated pattern is observed in the Central Amazon Basin, where the main spawning period of this species occurs at the beginning of the dry season (October) while water level is declining (Worthmann, 1992), evidencing species adaptation to different environments.
Samambaia station is located at the Samambaia River mouth, an area possibly used by Plagioscion squamosissimus for spawning or constituting a dispersion environment of larvae from Rodrigo's Lagoon (although called a lagoon, Rodrigo's Lagoon is located in a stretch of the Baía River). The current carries the larvae that find in the Baía River ideal conditions for their development. This explains the high catch and reduced size of the larvae in this river. Similar results were obtained in a previous period, where the largest larvae occurrence was also found in the Baía River (Baumgartner \& Nakatani, in prep.), reinforcing evidence of the importance of this environment in the Plagioscion squamosissimus occupation process on Upper Paraná River floodplain. Flow may be the determinant variable of the highest densities of Plagioscion squamosissimus larvae verified in the Baía River, since various studies have shown preference of the adults of the species for areas of low water flow or none at all (Chacon \& Silva, 1971), excellent adaptation of this species to dams (Nomura, 1973; Dourado, 1981), and its successful reservoir occupation (Cruz et al., 1990; Okada et al., 1996).

The high water level period is associated with high temperatures on the Upper Paraná River floodplain. In this study, the relationship between the great occurrence of larvae and high temperatures (shown by a positive Person's Correlation with this variable) corroborates Vazzoler et al. (1997), according to which the reproductive intensity (IR) in the fish community increases with rising water temperatures and duration of the day, variables that function as sex gland triggers in the maturation process. Although its effect is frequently masked by other environmental variables, temperature has considerable influence on fish development, growth, metabolism, and reproduction (Bagenal \& Braum, 1978 apud Herzig \& Winkler, 1986).

In the current study, "curvina" larvae occurred in high densities where the lowest dissolved oxygen values were recorded (Baía sub-area) (average of $\left.5.83 \mathrm{mgL}^{-1}\right)$. Similar results were found by Nakatani et al. (1993) at Itaipu Reservoir, where the larvae of this species were caught when dissolved oxygen values from 5.50 to $10.56 \mathrm{mg} / \mathrm{L}$ were found. Information on oxygen influence in the primary stages is unknown for species of the Upper Paraná 
River floodplain when hypoxia trail conditions are not possible or limited. Nevertheless, recorded values in the Baía sub-area for this environmental variable appear neither to limit nor favor this species in its development.

Another variable of great importance in aquatic environments is water $\mathrm{pH}$ which seems not to be determinant in fish larvae occurrence of Plagioscion squamosissimus, since its variations were always small with no extreme values, except in some lagoons where larvae occurrence was not significant. (This has been shown in successive studies on this floodplain.) A previous study on this floodplain showed similar results for this environmental variable (Baumgartner \& Nakatani, in prep.). Plagioscion squamosissimus larvae occurrence in Itaipu Reservoir was verified at $\mathrm{pH}$ from 6.96 to 8.13 (Nakatani et al., 1993), results similar to ours.

In the current study, higher larvae density was found in the Baía sub-area where low electrical conductivity values were recorded, while in Itaipu Reservoir Plagioscion squamosissimus larvae were caught in electrical conductivity from 55.33 to 71.66 $\mu \mathrm{S} / \mathrm{cm}$ (Nakatani et al., 1993), evidencing wide species tolerance to this environmental variable.

Although not widely used, an important variable to be considered when studying fish larvae is its capacity to avoid the sampling device. According to Morse (1989), net avoidance results in changes in the catch according to the light regime, larvae length, and species composition. Previous studies done in the Upper Paraná River (Baumgartner \& Nakatani, in prep.) and in Itaipu Reservoir (Nakatani et al., 1993) showed higher larvae catches at night. Based on this information, sampling for this study was done only at night. High larvae catches between 10 p.m. and 2 a.m. suggest Plagioscion squamosissimus larvae susceptibility to the catch device and/or higher larvae mobilization at this time due to reduced predator risk.

Analyses of captured larvae size show that the larvae use the Baía sub-area as a spawning and development site (especially at Samambaia and Rodrigo's Lagoon stations). The Paranapanema, Paraná, and especially Ivinheima sub-area (where the largest larvae occurred) were characterized as growth and dispersion environments of these larvae. In the Paranapanema sub-area, very small larvae occurrence may be the result of the spawning of some individuals or even of larvae drift from Porto Primavera dam.

The Baia River, especially in its upper portion where the Samambaia River mouth and Rodrigo's Lagoon are located, constitutes a highly important environment for the stock maintenance of this species in the Upper Paraná River floodplain, and possibly in the Itaipu Reservoir as well. Further studies involving sampling intensification in this river, especially in the Samambaia River and Rodrigo's Lagoon, will allow a model of this ecosystem to be constructed for Plagioscion squamosissimus occupation.

Acknowledgments — The authors are grateful to Nupélia (Núcleo de Pesquisas em Limnologia, Ictiologia e Aqüicultura) for logistical support and CNPq/PADCT/CIAMB for financing the project.

\section{REFERENCES}

AGOSTINHO, A. A., JÚliO Jr, H. F. \& PETRERE Jr, M., 1994, Itaipu reservoir (Brazil): impacts of the impoundment on the fish fauna and fisheries. In: U. G. Cowx (ed.), Rehabilitation of freshwater fisheries. Osney Mead, Oxford, Fishing News Books, pp. 171-184.

BAUMGARTNER, G., NAKATANI, K., CAVICCHIOLI, M. \& BAUMGARTNER, M. S. T., 1997, Some aspects of the ecology of fish larvae in the floodplain of the high Parana River, Brazil. Revta. Bras. Zool., 14(3): 551-563.

BAUMGARTNER, M. S. T. \& NAKATANI, K., (in prep.), Estudo preliminar da ocorrência de larvas de curvina na planície de inundação do alto rio Paraná, Brasil. Acta Scientiarum.

CHACON, J. O. \& SILVA, J. W. B., 1971, Alimentação da pescada-do-piauí, Plagioscion squamosissimus (Heckel). B. Cear. Agr., (12): 41-44.

CRUZ, J. A., MOREIRA, J. A., VERANI, J. R., GIRARDI, L. \& TORLONI, C. E. C., 1990, Levantamento da ictiofauna e aspectos da dinâmica de populações de algumas espécies do reservatório de Promissão, SP. (1ª etapa). CESP/UFSCar, São Paulo, 78p.

DELARIVA, R. L., AGOSTINHO, A. A., NAKATANI, K. \& BAUMGARGNER, G., 1994, Ichthyophauna associated to aquatic macrophytes in the upper Parana River floodplain. Rev. UNIMAR, 16: 41-60.

DOURADO, O. F., 1981, Principais peixes e crustáceos dos açudes controlados pelo DNOCS. SUDENE/DNOCS, Fortaleza, pp. 27-28.

ESTEVES, F. A., 1988, Fundamentos de limnologia. Interciência/Finep, Rio de Janeiro, 575p.

GOLTERMAN, H., CLYMO, R. S. \& OHMSTAD, M. A. M., 1978, Methods for physical and chemical analysis of fresh waters. Blackwell Scientific, Oxford, 214p. 
HAIR, J. F., ANDERSON, R. E., TATHAM, L. \& GRABLOWSKI, B. J., 1994, Multivariate data analysis. New York, McMillan, 360p.

HERZIG, A. \& WINKLER, H., 1986, The influence of temperature on the embryonic development of three cyprinid fishes, Abramis brama, Chalcalburnus chalcoides mento and Vimba vimba. J. Fish. Biol., 28: 171-81.

JACKSON, D. A., 1993, Stopping rules in principal components analysis: a comparison of heuristical and statistical approaches. Ecology, 74(8): 2204-2214.

JUNK, W., BAYLEY, P. B. \& SPARKS, R. E., 1989, The floodplain pulse concept in river-floodplain systems. Can. Spec. Publ. Fish Aqua. Sci., 106: 110-27.

LOWE-McCONNELL, R. H., 1975, Fish communities in tropical freshwaters. Longman, London, 337p.

MACHADO, C. E. M., 1974, Ação da CESP no meio ambiente. CESP, São Paulo, 38p. (Relatório interno).

MAINLY, B. F. J., 1995, Multivariate statistical methods: a primer. Chapman \& Hall, London, XIII + 215p.

McCUNE, B. \& MEFFORD, C., 1995, PC-ORD. Multivariate analysis of ecological data, version 2.0. MJM Software Design, Oregon, $v+126 p$.

MORSE, W. W., 1989, Catchability, growth and mortality of larval fishes. Fish. Bull., 87: 417-46.

NAKATANI, K., LATINI, J. D., BAUMGARTNER, G. \& BAUMGARTNER, M. S. T., 1993, Distribuição espacial e temporal das larvas de curvina Plagioscion squamosissimus (Heckel, 1840) (Osteichthyes, Sciaenidae), no reservatório de Itaipu. Rev. UNIMAR, 15: 191-209. Suplemento.

NAKATANI, K., BAUMGARTNER, G. \& BAUMGARTNER, M. S. T., 1997, Larval development of Plagioscion squamosissimus (Heckel, 1840) (Perciformes, Sciaenidae), of the Itaipu reservoir (Parana river - Brazil). Revta. Bras. Zool., 14(1): 35-44.

NOMURA, H., 1973, Peixes: pesca e biologia. Pisces, Rio de Janeiro, 143p.
NOMURA, H., 1984, Dicionário dos peixes do Brasil. Editerra, Brasília, 482p.

OKADA, E. K., AGOSTINHO, A. A. \& PETRERE Jr. M., 1996, Catch and effort data and the management of the commercial fisheries of Itaipu reservoir in the upper Paraná river, Brazil. In: U. G. Cowx (ed.), Stock assessment in inland fisheries. Osney Mead, Fishing News Books, Oxford, pp. 154-161.

PAIVA, M. P., 1982, Grandes represas do Brasil. Editerra, Brasília, 292p.

STATSOFT, 1999, Statistica ('99 edition): quick reference. StatSoft, Tulsa, 230p.

TANAKA, S., 1973, Stock assessment by means of ichthyoplankton surveys. FAO Fish. Tech. Pap., 122: 33-51.

TORLONI, C. E. C., SANTOS, J. J., CARVALHO Jr. A. A. \& CORRÊA, A. R. A., 1993, A pescada-do-piauí Plagioscion squamosissimus (Heckel, 1840) (Osteichthyes, Perciformes) nos reservatórios da CESP - Companhia Energética de São Paulo. CESP, São Paulo, 23p. (Série Pesquisa e desenvolvimento, 084).

VAZZOLER, A. E. A. M., 1996, Biologia da reprodução de peixes teleósteos: teoria e prática. EDUEM, Maringá, 169p.

VAZZOLER, A. E. A. M., SUZUKI, H. I., MARQUES, I. E. \& LIZAMA, M. A. P., 1997, Primeira maturação gonadal, períodos e áreas de reprodução. In: A. E. A. M. Vazzoler, A. A. Agostinho \& N. S. Hahn (eds.), A planície de inundação do alto rio Paraná: aspectos físicos, biológicos e socioeconômicos. EDUEM, Maringá, pp. 249-265.

WELCOMME, R. L., 1979, Fisheries ecology of floodplain rivers. Longman, London, 317p.

WORTHMANN, H. O., 1992, Aspekte der reproduktion zweier sciaenidenarten, der pescadas Plagioscion squamosissimus (Heckel, 1864) und Plagioscion monti (Soares, 1979), Pisces, in verschiedenen gewässertypen Zentral Amazoniens. Amazoniana, 12(1): 17-28. 